\title{
Influence of Integrated Nutrients on Growth and Yield Attributes of Wheat (Triticum aestivum L.) Crop [Cv.PBW-343] in Inseptisol
}

\author{
L. G. Ramanandan*, Narendra Swaroop, Arun Alferd David and Tarence Thomas
}

Department of Soil Science and Agricultural Chemistry, Naini Agricultural Institute Sam Higginbottom University of Agriculture, Technology and Sciences

Prayagraj-211 007, U.P., India

*Corresponding author

\begin{abstract}
A B S T R A C T
The influence of combined application of farm yard manure @ 5 tha $^{-1}$ and or integrated use of different nitrogen levels with seed inoculation of bio-fertilizers was resulted positive effect, under the topic entitled "Influence of integrated nutrients on growth and yield

\section{Keywords}

Bio-fertilizers, Farm Yard Manure (FYM), Integrated

Nutrient

Management (INM), Yield attributes, Productivity, etc.

\section{Article Info}

Accepted:

20 May 2020

Available Online:

10 June 2020 attributes of wheat (Triticum aestivum L.) crop [Cv.PBW-343] in Inseptisol" during cumulative study period of 2018-19 and 2019-20, at research farm, department of soil science and agricultural chemistry, Sam Higginbottom university of agriculture, technology and sciences, which is located at $25^{\circ} 58^{\prime} \mathrm{N}$ latitude and $81^{\circ} 52^{\prime}$ E longitude with an altitude of 98 meter above mean sea level and is situated $5 \mathrm{~km}$ away on the right bank of Yamuna river, Prayagraj District of Uttar Pradesh. Among twelve treatments, during field experimentation, the conjunctive use of farm yard manure, seed inoculation with Azatobacter spp and Azospirillum spp and different nitrogen levels, together come with best results significantly. However, the growth factors including pre-harvest parameters (like plant height, number of green leaves plant ${ }^{-1}$, number of tillers plant ${ }^{-1}$, dry weight plant $^{-1}$ which was observed at 30,60, 90 and 120 days after sowing, opined significantly highest in treatment $\left(\mathrm{T}_{9}\right)$ registering $75 \%$ nitrogen + farm yard manure @ $5 \mathrm{t}$ $\mathrm{ha}^{-1}+$ Azotobactor spp + Azospirillum $\mathrm{spp}\left(3 \mathrm{~kg} \mathrm{ha}^{-1}\right)+\mathrm{Zn}\left(\mathrm{ZnSO}_{4} @ 25 \mathrm{~kg} \mathrm{ha}^{-1}\right)$, which in turn ultimately gave the highest cumulative mean of economic productivity $\left(62.79 \mathrm{q} \mathrm{ha}^{-1}\right)$, straw yield $\left(93.52 \mathrm{q} \mathrm{ha}^{-1}\right)$, biological yield $\left(156.22 \mathrm{qha}^{-1}\right)$, percent harvest index $(40.13 \%)$,in comparison with chemical treatment $\left(\mathrm{T}_{3}\right)$ alone over control $\left(\mathrm{T}_{1}\right)$. Thus, integrated nutrient management pronounced its importance in the field of agriculture through supreme yield potential, diminishing the production cost and raising up soil health could be achieved.
\end{abstract}

\section{Introduction}

Wheat is the staple food in the traditional wheat growing northwest and central India. Wheat yields in largely irrigated northern
India (Punjab, Haryana, and Western Uttar Pradesh) are about 4.5 to 5.0 tha $^{-1}$, while grain yields in western and central states (Gujarat, Rajasthan, Madhya Pradesh, Bihar and parts of Uttar Pradesh) are relatively lower at 1.5 to 
3.0 tons per hectare, (Grain and Feed Annual 2019). Globally, wheat occupies respectively the first position in terms of acreage, hovering around 267 million hectares (mha) with an annual production of 902 million tonnes (MT). In India, Uttar Pradesh holds the first rank in wheat area (9.75 million ha) as well as production (31.88 million tonnes) during 2017-18, (Borse et al., 2019).On account of containing world energy crisis and spiraling prices of chemical fertilizer, by means of a high annual productivity of crops resulting in removal of nutrients in substantial amounts that exceed replenishment through chemical fertilizer and manures ultimately leading to poor soil health. Regarding lack of knowledge about the benefits of organic usages, people started using in-organic chemical fertilizers in indiscriminate way to maintain crop productivity. Such emerging trends of indiscriminate use of fertilizer without use of organic sources of nutrients are also responsible for deterioration of soil health. One of the best ways to optimize crop productivity and maintaining a healthy ecosystem, achieved by providing the necessary conditions and the need for greater use of bio-fertilizers and organics. Hence, the concept of integrated nutrient management which was assumed a greater importance in agricultural economy and has vital significance for meliorate and preserving soil health for heighten and substantiate agricultural production was of utmost importance for India's food and nutritional security. This challenge can be met by larger and more efficient use of fertilizers and organic sources. Thus, making yield supreme, diminishing the production cost and boosting up soil health could be achieved.

\section{Materials and Methods}

The experiment was conducted during the cumulative period, beginning from rabi seasons 2018-19 and 2019-20 at research farm, department of soil science and agricultural chemistry, Sam Higginbottom university of agriculture, technology and sciences, which is located at $25^{\circ} 58^{\prime}$ north latitude and $81^{\circ} 52^{\prime}$ east longitude with an altitude of 98 meter above mean sea level and is situated $5 \mathrm{~km}$ away on the right bank of Yamuna river, Prayagraj District of Uttar Pradesh.

The excavated soil sample from experimental site, mentioned that, the land topography range was nearly levelled with 1-3\% slope, soil is of sandy loam texture belongs to order Inceptisol and sub group Typic Ustipsamment with neutral to alkaline in reaction (6.82), electrical conductivity was non-saline $(0.30$ $\left.\mathrm{dSm}^{-1}\right)$ in nature, low organic carbon content $(0.319 \%)$, low to medium available nitrogen $\left(151 \mathrm{~kg} \mathrm{ha}^{-1}\right)$, available phosphrous $(14.80 \mathrm{~kg}$ $\left.\mathrm{ha}^{-1}\right)$ and available potassium $\left(240.3 \mathrm{~kg} \mathrm{ha}^{-1}\right)$.

The layout of the research field was depicted in randomized block design with twelve treatment combinations (Table 1) which is replicated thrice, recommended dose of fertilizers i.e. nitrogen, phosphrous and potassium $(100 \%)$ was applied in the ratio of 120:60:40 kg ha ${ }^{-1}$, respectively. The sources of nitrogen was through urea $(46 \% \mathrm{~N})$, phosphorus through single super phosphate $\left(16 \% \mathrm{P}_{2} \mathrm{O}_{5}\right)$, potash through muriate of potash $\left(60 \% \mathrm{~K}_{2} \mathrm{O}\right)$ and zinc through zinc sulphate ( $21 \% \mathrm{Zn}$ ). The bio-fertilizers i.e. Azotobacter spp and Azospirilium spp used as seed inoculant, was applied at $3 \mathrm{~kg} \mathrm{ha}^{-1}$ with $5 \mathrm{~kg}$ of well decomposed farm yard manureand was applied at $5 \mathrm{~cm}$ depth in furrows, just before the seed sowing which is carried out on $13^{\text {th }}$ and $14^{\text {th }}$ of November month during 2018 and 2019 with row spacing of $22.5 \mathrm{~cm}$ and plant spacing of $5 \mathrm{~cm}$.

Wheat cultivar PBW 343, an Attila sib, is a selection made at Punjab Agricultural University, Ludhiana, Punjab, India, from a 
set of lines called "Veery wheat derivatives" developed at CIMMYT, Mexico, based on an initial round of spring wheat $\times$ winter wheat hybridization. After its release in the North West Plain Zone (NWPZ) of India in1995, PBW 343 emerged as a mega cultivar.

The study hypothised that, the integrated nutrients like farmyard manure, nitrogen levels with zinc as micronutrient and biofertilizer i.e."nitroxin" containing Azotobactor spp and Azospirillum spp was used in testing the performance of wheat $\mathrm{cv}$. PBW-343 var (which is a popular, high yielding modern variety with medium to high tillering ability. It matures in 130-135 days and yields about 46-50q grain $\mathrm{ha}^{-1}$ ), and knowing nutrient availability in soil.

During, cumulative study period 2018-19 and 2019-20, the growth factors including preharvest parameters (like plant height, number of green leaves plant ${ }^{-1}$, number of tillers plant ${ }^{1}$, dry weight plant $^{-1}$, days taken to $50 \%$ spike head emergence, days taken to $50 \%$ flowering and days to physiological maturity) and postharvest parameters (like spike length, spike weight, number of grains spike ${ }^{-1}, 1000$ seed test weight, grain yield, straw yield, biological yield and harvest index), are discussed in brief as follows.

\section{Pre-harvest observations recorded during growth stages}

\section{Plant height (cm)}

Plant height was noted randomly from selected 5 tagged plants within a net plot area of experimental unit, from base of the plant to the base of the last fully opened leaf tip during vegetative phase at 30,60, 90 and 120 days after sowing. Mean average height of the five plants was calculated and then expressed in $\mathrm{cm}$.

\section{Number of green leaves plant ${ }^{-1}$}

To find out total number of green leaves produced plant $^{-1}$, all the leaves was counted from five randomly selected plants at 30, 60 and 90 days after sowing, their average was worked out and taken as the number of green leaves plant $^{-1}$.

\section{Dry matter accumulation plant ${ }^{-1}$ (gm)}

Five plant samples were collected randomly from each plot and uprooted carefully at 30, 60, 90 and 120 days after sowing. After removing roots, samples kept for sun drying for 2-3 days, later the plant samples were oven dried at $60-65^{\circ} \mathrm{C}$ for 48 hours to a constant weight. The sample was weighed on an electronic balance and average of it calculated and expressed in grams.

\section{Number of tillers plant ${ }^{-1}$}

From the five tagged plants which was selected at random at each plot, individually total number tillers were counted and mean of it taken into consideration at 30, 60,90 and 120 days after sowing.

\section{Days taken to fifty per cent ear head emergence}

A plant was observed daily for ear head emergence. Days taken to ear head emergence in wheat crop was recorded as the number of days on which fifty per cent tillers showed ears in the plot was considered as date of fifty per cent ear head emergence. The number of days taken from the date of sowing to heading was calculated and expressed in number of days taken for fifty per cent ear emergence.

\section{Days taken to fifty per cent flowering stage}

The plant was observed for flowering. The number of days taken from the date of sowing 
to flowering of the fifty per cent plants in each treatment was recorded.

\section{Days taken to physiological maturity}

Number of days to maturity of wheat was recorded from the date of sowing to the date when fifty per cent of plants showed yellowing or drying of straw of crop.

\section{Post-harvest observations recorded during growth stages}

\section{Length of spike (cm)}

Effective spike length was taken from wheat crop by selecting five healthy tagged plants at random from each plot during crop harvest. The average length of the panicle was measured with the scale from the base to the tip of the spike.

During spike length measurement awns were not included and mean was expressed in $\mathrm{cm}$.

\section{Weight of spike (gm)}

Recording the five worthy tagged plants of wheat crop from the experimental site, plot wise at harvest by using electronic balance and average of it was calculated.

\section{Number of grains spike ${ }^{-1}$}

Similarly, five spikes from randomly selected tagged plants in each plot at harvest were considered. These spikes have been threshed separately and counted total number of grains. The average of five spikes was taken as the number of grains spike ${ }^{-1}$.

\section{0 seed test weight (gm)}

Here one thousand grains were counted from each plot through random seed sampling and samples was kept for air drying in an oven at $60^{\circ} \mathrm{C}$ till the weight of the sample became constant later sample was weighed and expressed in grams.

\section{Grain yield (q ha $\left.{ }^{-1}\right)$}

After the harvesting of wheat crop produces from net plot, was threshed manually by beating them against hard surface, winnowed and cleaned separately.

The grain yield from each plot was recorded in $\mathrm{kg} \mathrm{plot}{ }^{-1}$ and finally converted into $\mathrm{q} \mathrm{ha}^{-1}$. Maintained wheat at 12 per cent moisture.

\section{Straw yield $\left(\mathrm{q} \mathrm{ha}^{-1}\right)$}

Before threshing operation to start, the bundle weight has been recorded plot wise which includes straw and grain. Later straw weight $(\mathrm{kg})$ was recorded after subtracting grain weight $(\mathrm{kg})$ from the whole bundle weight $(\mathrm{kg})$, which was then expressed in $\mathrm{q} \mathrm{ha}^{-1}$.

\section{Biological yield (q ha $\left.{ }^{-1}\right)$}

In order to know the biological yield of wheat crop, both the straw yield and grain yield from the bundle weight of each net plot was recorded two days after harvest and converted into $\mathrm{qha}^{-1}$.

\section{Harvest index (\%)}

The harvest index was calculated by using the formula given by Nichiporovich (1995)

$$
\begin{aligned}
& \text { Harvest index }(\%)= \\
& \qquad \frac{\text { Economic yield }}{\text { Biological yield }} \times 100
\end{aligned}
$$

Here, the economic yield was the grain yield and biological yield was the both grain and straw yield. 


\section{Statistical analysis}

The data averaged into respective parameter requisite was recorded and subjected to suitable transformation by "Analysis of variance technique". After analysis, data was accommodated in the table as per the needs of objectives for interpretation of results. For testing the hypothesis, the following ANOVA table was used. The significant and nonsignificant treatment effect was judged with the help of ' $F$ ' (variance ratio) table. If the calculated value exceeds the table value, the effect was considered to be significant. The standard procedures in agriculture statistics given by (Gomez, 1984), was consulted throughout. The interpretation of data will be done by using the critical difference value calculated at 0.05 probability level. The level of significance will be expressed at 0.05 probabilities.

\section{Results and Discussion}

The combined effect of organic nutrients and inorganic sources i.e. nitrogen levels on plant height, number of green leaves plant $^{-1}$, number of tillers plant ${ }^{-1}$, dry weight plant ${ }^{-1}$ of wheat at different growth intervals was observed at 30,60, 90 and 120 days after sowing, during the experimental year 2018-19 and 2019-20. In view to this, the data pertaining to plant height was found advanced and maximum at the stage of physiological maturity in applied sources and levels of nutrients imposed, during both the years of investigation.

At 30 days after sowing, it was noticed that on addition of calculated amount of plant nutrients through organic sources (farm yard manure, Azotobactor spp and Azospirillum spp) and in-organic nitrogen levels, increased plant height of the wheat crop compared to untreated plot (control), which showed nonsignificant in $\mathrm{T}_{9}(40.88 \mathrm{~cm}$ during 2018-19,
$41.05 \mathrm{~cm}$ during 2019-20 and $40.96 \mathrm{~cm}$ on pooled basis) when applied with $75 \% \mathrm{~N}+$ FYM @ $5 \mathrm{t} \mathrm{ha}^{-1}+$ Azotobactor + Azospirillum $\left(3 \mathrm{~kg} \mathrm{ha}^{-1}\right)+\mathrm{Zn}$, in comparison to control $\left(\mathrm{T}_{1}\right)$ i.e. $36.17,36.32$ and $35.30 \mathrm{~cm}$, followed by treatment $\left(\mathrm{T}_{6}\right)$ i.e. $75 \%$ nitrogen + farm yard manure @ 5 t ha ${ }^{-1}+$ Azotobactor spp + Azospirillum spp $\left(3 \mathrm{~kg} \mathrm{ha}^{-1}\right)$, i.e. $39.97,40.25$ and $40.11 \mathrm{~cm}$, respectively (table 2). Alike trend continues with respect to number of green leaves plant ${ }^{-1}$, i.e.7.23, 7.46 and 7.35, number of tillers plant $^{-1}$,i.e.3.26, 3.40 and 3.33, dry weight plant ${ }^{-1}$, i.e. $1.04,0.97$ and 1.01 gm, respectively, where they found significantly highest in treatment $\left(\mathrm{T}_{9}\right)$, in comparison to control $\left(\mathrm{T}_{1}\right)$,i.e. $6.00,6.80$ and $6.40,2.26,2.33$ and $2.30,0.90,0.83$ and 0.86 gm, respectively, during 2018-19, 2019-20 and on pooled basis, are presented in table 3,4 and 5.

Likewise, at 60 days after sowing, the plant height of wheat increased significantly to the magnitude of $62.66 \mathrm{~cm}, 62.83 \mathrm{~cm}$ and 62.74 $\mathrm{cm}$ (during 2018-19, 2019-20 and on pooled basis, respectively) was observed under the treatment $\left(\mathrm{T}_{9}\right)$ with $75 \%$ nitrogen + farm yard manure @ $5 \mathrm{t} \mathrm{ha}^{-1}+$ Azotobactor spp + Azospirillum spp $\left(3 \mathrm{~kg} \mathrm{ha}^{-1}\right)+$ zinc, followed by treatment $\left(\mathrm{T}_{6}\right)$ with $75 \%$ nitrogen + farm yard manure@5 t ha ${ }^{-1}+$ Azotobactor spp + Azospirillum spp $\left(3 \mathrm{~kg} \mathrm{ha}^{-1}\right)$, i.e. 61.75, 62.03 and $61.89 \mathrm{~cm}$, both were statistically at par with each other. The lowest plant height was recorded with treatment $T_{1}$ (untreated plot), i.e. $57.95,57.17$ and $57.08 \mathrm{~cm}$, respectively, (table 2). Similar result was found significantly highest with respect to number of green leaves plant ${ }^{-1}$, i.e. $20.23,22.03$ and 21.16, number of tillers plant ${ }^{-1}$, i.e. $6.76,6.96$, and 6.86, dry weight plant ${ }^{-1}, 11.83,12.66$ and $12.25 \mathrm{gm}$, respectively, at treatment $\left(\mathrm{T}_{9}\right)$, followed by treatment $\left(\mathrm{T}_{6}\right)$, i.e. $20.20,21.33$ and 20.66, 6.66, 6.83 and 6.75, 11.33, 12.66 and $12.16 \mathrm{gm}$, respectively. The lowest number of green leaves plant $^{-1}$, i.e. 15.80 , 
16.66 and 16.23, number of tillers plant ${ }^{-1}$, i.e.5.53, 5.63 and 5.58, dry weight plant $^{-}$ ${ }^{1}$,i.e.9.66, 10.00 and $9.83 \mathrm{gm}$, respectively, was recorded with treatment $\mathrm{T}_{1}$ (untreated plot). The data are presented in table 3, 4and 5 .

Significantly lesser observations, with regard to plant height,i.e.118.44, 119.48 and 118.53 $\mathrm{cm}$, number of green leaves plant ${ }^{-1}$, i.e.32.00, 34.33 and 33.16, number of tillers plant ${ }^{-1}$, i.e.9.00, 9.33 and 9.16, dry weight plant ${ }^{1}$,i.e. $15.43,16.20$ and15.66 gm, respectively, was noted in treatment $\left(\mathrm{T}_{1}\right)$, when compared with highest treatment $\left(\mathrm{T}_{9}\right)$, i.e. $123.45,123.62$ and $123.53 \mathrm{~cm}, 39.33,41.00$ and $40.16,11.16$ and 12.46, 11.83, 17.83, 18.90 and $18.00 \mathrm{gm}$, respectively, during both years as well as on pooled basis at 90 days after sowing. The data are presented in table 2, 3, 4 and 5.

But at 120 days after sowing, parameters like plant height ${ }^{-1}$, number of tillers plant ${ }^{-1}$ and dry weightplant ${ }^{-1}$ are considered and result was proved significantly highest in treatment $\left(\mathrm{T}_{9}\right)$, i.e. $125.24,125.41$ and $125.32 \mathrm{~cm}, 13.50$, 11.50 and $13.08,21.96,23.33$ and $22.50 \mathrm{gm}$, respectively, as followed by treatment $\left(\mathrm{T}_{6}\right)$, i.e. $124.20,124.48$ and $124.34 \mathrm{~cm}, 12.43,13.16$ and $12.75,21.53,23.00$ and $22.16 \mathrm{gm}$, respectively, over control $\left(\mathrm{T}_{1}\right)$, i.e.119.35, 120.00 and $119.94 \mathrm{~cm}, 10.13,10.83$ and $10.58, \quad 19.06,20.50$ and $19.78 \mathrm{gm}$, respectively, which was found lowest, during both years as well as on pooled basis. The data are presented in table 2, 4 and 5.

The advancement of higher plant height between the crop growth period, the reason might be indicating that better effect pronounced with synchronized availability of essential plant nutrients to the crop. Similar, findings were also recorded (Brar et al., 2015).

The increased height of wheat plants at different growth stages with the increase levels of fertilizer and farm yard manure which might be attributed to the increase in the length of internodes and the number of internodes per stem (Rehman et al., 2010) and because of their slow release of nutrients, besides supplying other micro-nutrients essential to plant growth (Ghanshyam et al., 2010) Moreover, nitrogen encourages the cell elongation, cell division and cell multiplication leading to an overall increasing in vegetative growth wheat plant particularly plant height. The results from the experimental field are in harmony with findings (Kaushik et al., 2012) (Singh et al., 2013) (Soleimanzadeh and Gooshchi, 2013).

It might be the reason that, increasing in translocation and transportation of $\mathrm{N}$ and $\mathrm{P}$ by biological supply results in more chlorophyll content intern a greater number of green leaves per plant at all stages. The balanced supply of nutrients plays an important role for rapid growth and development of a crop. Organic manures supply both macro and micro-nutrients and also improve the availability of native nutrients. Hence higher the plant growth, higher number of green leaves obtained. Similar findings are in collaboration (Amanullah et al., 2014) (Lehoczky et al., 2012) (Ali et al., 2015).

Consequently, increased nutrient content in soil in combination of organics and inorganics increased the respective nutrient content in the plants at tillering stage resulting in a significant increase in number of tillers plant ${ }^{-1}$ (Sharma, 2009) (Jat et al., 2013). The progressive development on number of tillers plant ${ }^{-1}$ led by the vegetative and reproductive growth of the plant which affected positively by application of organic manures i.e. FYM and vermicompost and supply of photosynthates for the formation of yield components. These results are in agreement with those reported (Yadav et al., 2009) and (Verma et al., 2015). 
The reason for increasing trend in dry matter accumulation in $\mathrm{T}_{9}$ might be due to organic matter content in soil and its uptake by crop plant for its growth improvement directly or indirectly. Large amount of macro nutrients and micro nutrients are present in the organic matter and humic is a substance which is produce in the soil by the decomposition of organic material and this material is very useful for the growth of the plant (Noreen and Noreen, 2014; Chopra et al., 2016; Meena et al., 2013; Pandey and Singh, 2015).

Direct relationship existed between preharvest and post-harvest parameters with respect to grain yield, straw yield, biological yield and harvest index, which paid the way for maximizing the production and productivity of wheat crop during the cumulative study period.

Significantly highest grain yield of 61.20, 64.38 and $62.79 \mathrm{q} \mathrm{ha}^{-1}$, straw yield of 92.35 , 94.70 and $93.52 \mathrm{q} \mathrm{ha}^{-1}$, biological yield of 153.37, 159.08 and $156.22 \mathrm{q} \mathrm{ha}^{-1}$, and percent harvest index with of 39.79, 40.46 and 40.13 $\%$, respectively, was opined in treatment $\left(\mathrm{T}_{9}\right)$ registering $75 \% \mathrm{~N}+\mathrm{FYM} @ 5 \mathrm{t} \mathrm{ha}^{-1}+$ Azotobactor + Azospirillum $\left(3 \mathrm{~kg} \mathrm{ha}^{-1}\right)+\mathrm{Zn}$ $\left(\mathrm{ZnSO}_{4} @ 25 \mathrm{~kg} \mathrm{ha}^{-1}\right)$ in comparison with $\mathrm{T}_{3}$ having $100 \% \mathrm{RDF}$ alone, i.e. grain yield (44.52, 45.40 and $44.96 \mathrm{q} \mathrm{ha}^{-1}$ ), straw yield (68.34, 72.77 and $70.53 \mathrm{q} \mathrm{ha}^{-1}$ ), biological yield (112.86, 118.17 and $115.52 \mathrm{q} \mathrm{ha}^{-1}$ ) and percent harvest index $(39.42,38.42$ and 38.92 $\%)$ over control $\left(\mathrm{T}_{1}\right)$,i.e.25.38, 25.86 and $25.62 \mathrm{q} \mathrm{ha}^{-1}$ in grain yield, 42.42, 44.78 and $43.54 \mathrm{q} \mathrm{ha}^{-1}$ in straw yield,67.80, 70.64 and $69.22 \mathrm{q} \mathrm{ha}^{-1}$ in biological yield and 36.15, 36.36 and $36.26 \%$, in harvest index, which was found lowest, during 2018-19, 2019-20 and on pooled basis.

However, treatment $\left(\mathrm{T}_{9}\right)$, followed by treatment $\left(\mathrm{T}_{6}\right),[75 \%$ nitrogen +farm yard manure @ 5 t ha ${ }^{-1}+$ Azotobactor spp +
Azospirillum spp $\left.\left(3 \mathrm{~kg} \mathrm{ha}^{-1}\right)\right]$, i.e. 54.15, 54.65, $54.40 \mathrm{q} \mathrm{ha}^{-1}$ of grain yield,80.30, 90.79, 85.54 $\mathrm{q}$ ha $^{-1}$ of straw yield,134.45, 145.30, $139.88 \mathrm{q}$ $\mathrm{ha}^{-1}$ of biological yield and percent harvest index withof 42.21, 39.74 and $40.98 \%$, respectively, in which both are statistically at par with each other, during both the years and on pooled basis. The data are presented in table 6 and 7 .

It might be also due to steady decomposition of farm yard manure and release of nutrients throughout the crop growth period coupled with better nutrient assimilation in developing reproductive structures, greater availability of metabolites (photosynthates), have resulted positive information of yield components which ultimately improved the yield of the crop. Similar findings are in collaboration (Kumar et al., 2015; Singh et al., 2016; Singh et al., 2010; Zahoor, 2014).

The reason for increase in grain and straw yield as well as harvest index, might be due to application of zinc fertilizer, which play an important role in biosynthesis of the indole acetic acid and initiation of primordia for reproductive parts and a result of favourable effect of zinc on the metabolic reactions within the plants. The results are in close conformity with findings (Goswami, 2007; Singh et al., 2012).

The significant enhancement of biological yield and harvest index, in organically treated plot, might be due to double-inoculation of Azotobacter spp. and Azospirillum spp. with its positive effect in increasing nitrite production which in-turn increases formation of lateral roots. And also increasing nitrate accumulation reflects on increased biomass and nitrate content. The results are in conformity (Bashan et al., 2005) (Jat et al., 2013) (Patel et al., 2014) (Kandil et al., 2011). 
Table.1 Experimental treatment combination of in-organic fertilizer, organic manure and bio-fertilizers

\begin{tabular}{|c|c|}
\hline Treatments & Rabi(Wheat-var PBW-343) \\
\hline $\mathbf{T}_{1}$ & Absolute control \\
\hline $\mathbf{T}_{2}$ & $75 \% \mathrm{~N}$ \\
\hline $\mathbf{T}_{\mathbf{3}}$ & $\mathrm{N}_{120} \mathrm{P}_{60} \mathrm{~K}_{40}$ \\
\hline $\mathbf{T}_{4}$ & $\mathrm{~T}_{2}+\mathrm{FYM} @ 5 \mathrm{tha}^{-1}$ \\
\hline $\mathbf{T}_{5}$ & $\mathrm{~T}_{2}+$ Azotobactor spp and Azospirillum spp @ $3 \mathrm{~kg} \mathrm{ha}^{-1}$ \\
\hline $\mathbf{T}_{6}$ & $\mathrm{~T}_{4}+$ Azotobactor spp and Azospirillum spp @3kg ha ${ }^{-1}$ \\
\hline $\mathbf{T}_{7}$ & $\mathrm{~T}_{2}+\mathrm{Zn} @ 25 \mathrm{kgha}^{-1}$ \\
\hline $\mathbf{T}_{8}$ & $\mathrm{~T}_{4}+\mathrm{Zn} @ 25 \mathrm{kgha}^{-1}$ \\
\hline $\mathbf{T}_{9}$ & $\mathrm{~T}_{5}+\mathrm{Zn} @ 25 \mathrm{kgha}^{-1}$ \\
\hline $\mathbf{T}_{10}$ & $50 \% \mathrm{~N}+\mathrm{FYM} @ 5 \mathrm{tha}^{-1}$ \\
\hline $\mathbf{T}_{11}$ & $50 \% \mathrm{~N}+$ Azotobactor spp and Azospirillum spp @ $3 \mathrm{~kg} \mathrm{ha}^{-1}$ \\
\hline $\mathbf{T}_{\mathbf{1 2}}$ & $\mathrm{T}_{10}+$ Azotobactor spp and Azospirillum spp @3 $\mathrm{kg} \mathrm{ha}^{-1}+\mathrm{Zn} @ 25 \mathrm{kgha}^{-1}$ \\
\hline
\end{tabular}

Note: Basal dose of phosphorus $\left(60 \mathrm{~kg} \mathrm{ha}^{-1}\right)$, potassium $\left(40 \mathrm{~kg} \mathrm{ha}^{-1}\right)$ and zinc sulphate $\left(25 \mathrm{~kg} \mathrm{ha}^{-1}\right)$ was applied at the start of the experiment

Table.2 Effect on plant height $(\mathrm{cm})$ at different growth intervals of wheat as influenced by sources and nitrogen levels

\begin{tabular}{|c|c|c|c|c|c|c|c|c|c|c|c|c|}
\hline \multirow[t]{3}{*}{$\mathbf{T}$} & \multicolumn{12}{|c|}{ Plant height (cm) in DAS (Days After Sowing) } \\
\hline & \multicolumn{4}{|c|}{ 2018-19 } & \multicolumn{4}{|c|}{ 2019-20 } & \multicolumn{4}{|c|}{ Pooled } \\
\hline & 30 & 60 & 90 & 120 & 30 & 60 & 90 & 120 & 30 & 60 & 90 & 120 \\
\hline $\mathbf{T}_{1}$ & 36.17 & 57.95 & 118.44 & 119.35 & 36.32 & 57.17 & 119.48 & 120.01 & 35.30 & 57.08 & 118.53 & 119.94 \\
\hline $\mathbf{T}_{2}$ & 37.60 & 60.08 & 118.74 & 120.41 & 38.11 & 58.10 & 118.89 & 120.56 & 36.24 & 59.45 & 118.81 & 120.48 \\
\hline $\mathbf{T}_{3}$ & 39.23 & 61.01 & 121.80 & 121.11 & 37.91 & 59.69 & 119.16 & 121.31 & 37.81 & 61.58 & 120.38 & 121.21 \\
\hline $\mathbf{T}_{4}$ & 38.73 & 60.51 & 121.30 & 122.02 & 38.92 & 60.70 & 121.49 & 122.21 & 39.31 & 60.79 & 121.88 & 122.12 \\
\hline $\mathbf{T}_{5}$ & 37.70 & 59.48 & 120.27 & 121.03 & 37.88 & 59.66 & 120.45 & 121.21 & 37.79 & 59.57 & 120.36 & 121.12 \\
\hline $\mathbf{T}_{6}$ & 39.97 & 61.75 & 122.54 & 124.20 & 40.25 & 62.03 & 122.82 & 124.48 & 40.11 & 61.89 & 122.68 & 124.34 \\
\hline $\mathbf{T}_{7}$ & 37.97 & 59.38 & 120.17 & 120.81 & 37.74 & 59.52 & 120.31 & 120.95 & 37.67 & 60.15 & 120.24 & 120.88 \\
\hline $\mathbf{T}_{8}$ & 39.67 & 61.45 & 119.87 & 122.90 & 39.92 & 61.70 & 121.96 & 123.05 & 39.80 & 61.09 & 121.58 & 122.98 \\
\hline $\mathbf{T}_{9}$ & 40.88 & 62.66 & 123.45 & 125.24 & 41.05 & 62.83 & 123.62 & 125.41 & 40.96 & 62.74 & 123.53 & 125.32 \\
\hline$T_{10}$ & 35.20 & 56.98 & 118.90 & 121.47 & 35.39 & 60.22 & 118.63 & 121.66 & 38.04 & 58.02 & 119.03 & 121.56 \\
\hline$T_{11}$ & 37.71 & 59.49 & 120.28 & 120.44 & 39.39 & 60.86 & 120.48 & 120.70 & 39.01 & 59.59 & 119.42 & 120.57 \\
\hline$T_{12}$ & 38.93 & 60.71 & 121.50 & 122.73 & 39.08 & 61.17 & 121.65 & 122.89 & 38.83 & 60.61 & 121.40 & 122.81 \\
\hline F test & NS & $\mathbf{S}$ & $\mathbf{S}$ & $\mathbf{S}$ & NS & $\mathbf{S}$ & S & $\mathbf{S}$ & NS & $\mathbf{S}$ & $\mathbf{S}$ & $\mathbf{S}$ \\
\hline S. Ed. & 1.600 & 1.138 & 1.417 & 1.475 & 1.600 & 1.138 & 1.417 & 1.475 & 1.600 & 1.138 & 1.417 & 1.475 \\
\hline C. D. & 3.302 & 2.349 & 2.925 & 3.045 & 3.302 & 2.349 & 2.925 & 3.045 & 3.302 & 2.349 & 2.925 & 3.045 \\
\hline
\end{tabular}


Table.3 Effect on number of green leaves plant ${ }^{-1}$ at different growth intervals of wheat as influenced by sources and nitrogen levels

\begin{tabular}{|c|c|c|c|c|c|c|c|c|c|}
\hline \multirow[t]{3}{*}{$\mathbf{T}$} & \multicolumn{9}{|c|}{ Number of green leaves plant ${ }^{-1}$ in DAS (Days After Sowing) } \\
\hline & \multicolumn{3}{|c|}{ 2018-19 } & \multicolumn{3}{|c|}{ 2019-20 } & \multicolumn{3}{|c|}{ Pooled } \\
\hline & 30 & 60 & 90 & 30 & 60 & 90 & 30 & 60 & 90 \\
\hline $\mathbf{T}_{\mathbf{1}}$ & 6.00 & 15.80 & 32.00 & 6.80 & 16.66 & 34.33 & 6.40 & 16.23 & 33.16 \\
\hline $\mathbf{T}_{2}$ & 6.13 & 16.13 & 34.23 & 6.96 & 18.06 & 36.43 & 6.55 & 17.16 & 35.33 \\
\hline $\mathbf{T}_{3}$ & 6.53 & 18.03 & 36.00 & 7.20 & 19.48 & 38.29 & 6.83 & 18.83 & 37.16 \\
\hline $\mathbf{T}_{4}$ & 6.86 & 18.86 & 36.66 & 7.13 & 20.61 & 39.00 & 7.00 & 19.66 & 37.83 \\
\hline $\mathbf{T}_{5}$ & 6.26 & 17.86 & 35.00 & 7.06 & 19.12 & 38.00 & 6.73 & 18.33 & 36.66 \\
\hline $\mathbf{T}_{6}$ & 7.10 & 20.20 & 38.67 & 7.40 & 21.33 & 40.65 & 7.25 & 20.66 & 39.66 \\
\hline $\mathbf{T}_{7}$ & 6.20 & 17.10 & 34.36 & 7.03 & 18.62 & 37.66 & 6.65 & 17.83 & 36.33 \\
\hline $\mathbf{T}_{8}$ & 7.03 & 19.46 & 38.19 & 7.20 & 21.01 & 40.14 & 7.11 & 20.33 & 39.16 \\
\hline $\mathbf{T}_{9}$ & 7.23 & 20.23 & 39.33 & 7.46 & 22.03 & 41.00 & 7.35 & 21.16 & 40.16 \\
\hline $\mathbf{T}_{10}$ & 6.46 & 18.20 & 36.04 & 7.26 & 20.00 & 38.66 & 6.90 & 19.16 & 37.33 \\
\hline $\mathbf{T}_{11}$ & 6.40 & 16.53 & 35.33 & 6.96 & 18.77 & 37.03 & 6.58 & 17.50 & 35.66 \\
\hline $\mathbf{T}_{12}$ & 7.00 & 18.96 & 37.35 & 7.13 & 21.00 & 39.31 & 7.06 & 19.83 & 38.33 \\
\hline F- test & $\mathbf{S}$ & $\mathbf{S}$ & $\mathbf{S}$ & $\mathbf{S}$ & $\mathbf{S}$ & $\mathbf{S}$ & $\mathbf{S}$ & $\mathbf{S}$ & $\mathbf{S}$ \\
\hline S. Ed. & 0.288 & 1.641 & 1.581 & 0.156 & 1.445 & 1.294 & 0.175 & 1.543 & 1.144 \\
\hline C. D. & 0.602 & 2.062 & 3.300 & 0.326 & 3.017 & 2.701 & 0.366 & 2.539 & 2.387 \\
\hline
\end{tabular}

Table.4 Effect on number of tillers plant ${ }^{-1}$ at different growth intervals of wheat as influenced by different sources and nitrogen levels

\begin{tabular}{|c|c|c|c|c|c|c|c|c|c|c|c|c|}
\hline \multirow[t]{3}{*}{$\mathbf{T}$} & \multicolumn{12}{|c|}{ Number of tillers plant ${ }^{-1}$ in DAS (Days After Sowing) } \\
\hline & \multicolumn{4}{|c|}{ 2018-19 } & \multicolumn{4}{|c|}{ 2019-20 } & \multicolumn{4}{|c|}{ Pooled } \\
\hline & 30 & 60 & 90 & 120 & 30 & 60 & 90 & 120 & 30 & 60 & 90 & 120 \\
\hline $\mathbf{T}_{1}$ & 2.26 & 5.53 & 09.00 & 10.13 & 2.33 & 5.63 & 09.33 & 10.83 & 2.30 & 5.58 & 09.16 & 10.58 \\
\hline $\mathbf{T}_{2}$ & 2.55 & 5.99 & 09.33 & 11.03 & 2.61 & 5.93 & 09.60 & 11.44 & 2.50 & 5.93 & 09.50 & 11.41 \\
\hline $\mathbf{T}_{\mathbf{3}}$ & 2.78 & 6.23 & 10.08 & 11.90 & 2.94 & 6.36 & 10.42 & 12.59 & 2.86 & 6.30 & 10.25 & 12.00 \\
\hline $\mathbf{T}_{4}$ & 2.90 & 6.43 & 10.33 & 12.20 & 3.10 & 6.56 & 10.83 & 12.67 & 3.00 & 6.50 & 10.58 & 12.33 \\
\hline $\mathbf{T}_{5}$ & 2.73 & 6.13 & 09.50 & 11.23 & 2.86 & 6.26 & 10.01 & 12.16 & 2.80 & 6.20 & 09.75 & 11.75 \\
\hline$T_{6}$ & 3.10 & 6.66 & 11.00 & 12.43 & 3.36 & 6.83 & 11.66 & 13.16 & 3.23 & 6.75 & 11.33 & 12.75 \\
\hline $\mathbf{T}_{7}$ & 2.60 & 6.10 & 09.45 & 11.16 & 2.76 & 6.23 & 10.05 & 12.00 & 2.68 & 6.16 & 09.75 & 11.66 \\
\hline $\mathbf{T}_{8}$ & 3.03 & 6.60 & 10.64 & 12.36 & 3.26 & 6.76 & 11.35 & 13.02 & 3.15 & 6.68 & 11.00 & 12.58 \\
\hline $\mathbf{T}_{9}$ & 3.26 & 6.76 & 11.16 & 12.46 & 3.40 & 6.96 & 11.83 & 13.50 & 3.33 & 6.86 & 11.50 & 13.08 \\
\hline$T_{10}$ & 2.83 & 6.33 & 10.16 & 11.93 & 3.03 & 6.46 & 10.66 & 12.66 & 2.93 & 6.40 & 10.41 & 12.25 \\
\hline $\mathbf{T}_{11}$ & 2.39 & 5.93 & 09.38 & 11.06 & 2.64 & 6.14 & 09.66 & 11.52 & 2.60 & 6.06 & 09.50 & 11.45 \\
\hline $\mathbf{T}_{12}$ & 3.00 & 6.31 & 10.27 & 12.26 & 3.20 & 6.88 & 11.39 & 13.02 & 3.10 & 6.58 & 10.83 & 12.58 \\
\hline F- test & $\mathbf{S}$ & $\mathbf{S}$ & $\mathbf{S}$ & $\mathbf{S}$ & $\mathbf{S}$ & $\mathbf{S}$ & $\mathbf{S}$ & $\mathbf{S}$ & $\mathbf{S}$ & $\mathbf{S}$ & $\mathbf{S}$ & $\mathbf{S}$ \\
\hline S. Ed. & 0.112 & 0.148 & 0.614 & 0.675 & 0.126 & 0.159 & 0.653 & 0.602 & 0.080 & 0.139 & 0.579 & 0.386 \\
\hline C. D. & 0.233 & 0.310 & 1.282 & 1.002 & 0.263 & 0.333 & 1.363 & 1.256 & 0.167 & 0.290 & 1.208 & 0.805 \\
\hline
\end{tabular}


Table.5 Effect on dry matter accumulation plant ${ }^{-1}$ at different growth intervals of wheat as influenced by different sources and nitrogen levels

\begin{tabular}{|c|c|c|c|c|c|c|c|c|c|c|c|c|}
\hline \multirow[t]{3}{*}{$\mathbf{T}$} & \multicolumn{12}{|c|}{ Dry matter accumulation plant ${ }^{-1}$ in DAS (Days After Sowing) } \\
\hline & \multicolumn{4}{|c|}{ 2018-19 } & \multicolumn{4}{|c|}{ 2019-20 } & \multicolumn{4}{|c|}{ Pooled } \\
\hline & 30 & 60 & 90 & 120 & 30 & 60 & 90 & 120 & 30 & 60 & 90 & 120 \\
\hline $\mathbf{T}_{1}$ & 0.90 & 9.66 & 15.43 & 19.06 & 0.83 & 10.00 & 16.20 & 20.50 & 0.86 & 9.83 & 15.66 & 19.78 \\
\hline $\mathbf{T}_{2}$ & 0.94 & 10.40 & 16.40 & 20.20 & 0.87 & 10.66 & 16.73 & 21.16 & 0.90 & 10.50 & 16.66 & 20.58 \\
\hline $\mathbf{T}_{\mathbf{3}}$ & 0.97 & 10.93 & 17.10 & 20.46 & 0.91 & 11.16 & 17.26 & 22.00 & 0.95 & 11.16 & 17.33 & 21.50 \\
\hline $\mathbf{T}_{4}$ & 0.99 & 11.10 & 17.20 & 20.77 & 0.91 & 11.66 & 17.40 & 22.50 & 0.96 & 11.41 & 17.58 & 21.66 \\
\hline $\mathbf{T}_{5}$ & 0.96 & 10.86 & 17.03 & 20.46 & 0.90 & 11.00 & 17.23 & 21.66 & 0.93 & 10.75 & 16.91 & 21.08 \\
\hline $\mathbf{T}_{6}$ & 1.02 & 11.33 & 17.70 & 21.53 & 0.95 & 12.66 & 18.70 & 23.00 & 0.99 & 12.16 & 17.83 & 22.16 \\
\hline $\mathbf{T}_{7}$ & 0.96 & 10.63 & 16.86 & 20.43 & 0.90 & 11.00 & 17.20 & 21.66 & 0.93 & 10.83 & 17.16 & 21.08 \\
\hline $\mathbf{T}_{8}$ & 1.01 & 11.26 & 17.56 & 21.20 & 0.93 & 12.00 & 18.06 & 22.83 & 0.98 & 11.66 & 17.81 & 22.08 \\
\hline $\mathbf{T}_{9}$ & 1.04 & 11.83 & 17.83 & 21.96 & 0.97 & 12.66 & 18.90 & 23.33 & 1.01 & 12.25 & 18.00 & 22.50 \\
\hline $\mathbf{T}_{10}$ & 0.99 & 11.02 & 17.15 & 20.60 & 0.92 & 11.33 & 17.30 & 22.33 & 0.94 & 11.00 & 17.25 & 21.33 \\
\hline $\mathbf{T}_{11}$ & 0.95 & 10.53 & 16.73 & 20.30 & 0.89 & 10.66 & 17.10 & 21.33 & 0.93 & 10.50 & 16.83 & 20.75 \\
\hline $\mathbf{T}_{12}$ & 1.00 & 11.10 & 17.53 & 21.03 & 0.93 & 12.00 & 17.53 & 22.83 & 0.96 & 11.66 & 17.50 & 21.91 \\
\hline F- test & $\mathbf{S}$ & $\mathbf{S}$ & $\mathbf{S}$ & $\mathbf{S}$ & $\mathbf{S}$ & $\mathbf{S}$ & $\mathbf{S}$ & $\mathbf{S}$ & $\mathbf{S}$ & $\mathbf{S}$ & $\mathbf{S}$ & $\mathbf{S}$ \\
\hline S. Ed. & 0.052 & 0.627 & 0.649 & 0.691 & 0.014 & 0.576 & 0.589 & 0.609 & 0.028 & 0.436 & 0.301 & 0.451 \\
\hline C. D. & 0.040 & 1.003 & 1.012 & 0.120 & 0.030 & 1.202 & 1.229 & 0.280 & 0.058 & 0.909 & 0.628 & 0.940 \\
\hline
\end{tabular}


Table.6 Effect on post harvest parameters during wheat cultivation as influenced by different sources and nitrogen levels

\begin{tabular}{|c|c|c|c|c|c|c|}
\hline \multirow[t]{2}{*}{ Treatments } & \multicolumn{3}{|c|}{ Grain yield $\left(q\right.$ ha $\left.^{-1}\right)$} & \multicolumn{3}{|c|}{ Straw yield $\left(q\right.$ ha $\left.^{-1}\right)$} \\
\hline & 2018-19 & 2019-20 & Pooled & 2018-19 & 2019-20 & Pooled \\
\hline $\mathbf{T}_{1}$ & 25.38 & 25.86 & 25.62 & 42.42 & 44.78 & 43.54 \\
\hline $\mathbf{T}_{2}$ & 33.27 & 33.77 & 33.52 & 58.68 & 59.09 & 58.86 \\
\hline $\mathbf{T}_{\mathbf{3}}$ & 44.52 & 45.40 & 44.96 & 68.34 & 72.77 & 70.53 \\
\hline $\mathbf{T}_{4}$ & 49.59 & 50.06 & 49.83 & 76.63 & 77.13 & 76.88 \\
\hline $\mathbf{T}_{5}$ & 44.16 & 44.63 & 44.40 & 69.29 & 67.75 & 68.52 \\
\hline $\mathbf{T}_{6}$ & 54.15 & 54.65 & 54.40 & 80.30 & 90.79 & 85.54 \\
\hline $\mathbf{T}_{7}$ & 40.66 & 41.14 & 40.90 & 63.00 & 64.02 & 63.54 \\
\hline $\mathbf{T}_{8}$ & 51.70 & 52.19 & 51.94 & 81.30 & 85.77 & 83.53 \\
\hline $\mathbf{T}_{9}$ & 61.20 & 64.38 & 62.79 & 92.35 & 94.70 & 93.52 \\
\hline $\mathbf{T}_{10}$ & 48.19 & 48.64 & 48.42 & 71.26 & 77.80 & 74.55 \\
\hline $\mathbf{T}_{11}$ & 40.66 & 41.10 & 40.88 & 55.61 & 62.37 & 59.54 \\
\hline $\mathbf{T}_{12}$ & 50.61 & 51.06 & 50.83 & 79.97 & 80.41 & 80.19 \\
\hline F- test & $\mathbf{S}$ & $\mathbf{S}$ & $\mathbf{S}$ & $\mathbf{S}$ & $\mathbf{S}$ & $\mathbf{S}$ \\
\hline S. Ed. $( \pm)$ & 1.894 & 1.217 & 0.995 & 2.576 & 1.507 & 1.451 \\
\hline C. D. $(P=0.05)$ & 3.954 & 2.540 & 2.077 & 5.378 & 3.145 & 3.029 \\
\hline
\end{tabular}


Table.7 Effect on post harvest parameters during wheat cultivation as influenced by different sources and nitrogen levels

\begin{tabular}{|c|c|c|c|c|c|c|}
\hline \multirow[t]{2}{*}{ Treatments } & \multicolumn{3}{|c|}{ Biological yield (q ha $\left.{ }^{-1}\right)$} & \multicolumn{3}{|c|}{ Harvest index $(\%)$} \\
\hline & 2018-19 & 2019-20 & Pooled & 2018-19 & 2019-20 & Pooled \\
\hline $\mathbf{T}_{1}$ & 67.80 & 70.64 & 69.22 & 36.15 & 36.36 & 36.26 \\
\hline $\mathbf{T}_{2}$ & 91.75 & 92.85 & 92.30 & 37.46 & 36.60 & 37.03 \\
\hline $\mathbf{T}_{\mathbf{3}}$ & 112.86 & 118.17 & 115.52 & 39.42 & 38.42 & 38.92 \\
\hline $\mathbf{T}_{4}$ & 126.21 & 127.12 & 126.67 & 38.92 & 39.71 & 39.32 \\
\hline $\mathbf{T}_{5}$ & 113.46 & 112.38 & 112.92 & 40.31 & 37.49 & 38.90 \\
\hline $\mathbf{T}_{6}$ & 134.45 & 145.30 & 139.88 & 42.21 & 39.74 & 40.98 \\
\hline $\mathbf{T}_{7}$ & 103.66 & 105.49 & 104.58 & 38.80 & 38.83 & 38.82 \\
\hline $\mathbf{T}_{8}$ & 133.00 & 137.9 & 135.48 & 40.30 & 38.47 & 39.39 \\
\hline $\mathbf{T}_{9}$ & 153.37 & 159.08 & 156.22 & 39.79 & 40.46 & 40.13 \\
\hline $\mathbf{T}_{10}$ & 119.45 & 126.43 & 122.94 & 39.24 & 39.32 & 39.28 \\
\hline $\mathbf{T}_{11}$ & 96.27 & 103.50 & 99.89 & 38.87 & 37.80 & 38.34 \\
\hline $\mathbf{T}_{12}$ & 130.58 & 131.47 & 131.02 & 39.34 & 39.36 & 39.35 \\
\hline F- test & $\mathbf{S}$ & $\mathbf{S}$ & $\mathbf{S}$ & $\mathbf{S}$ & $\mathbf{S}$ & $\mathbf{S}$ \\
\hline S. Ed. $( \pm)$ & 3.076 & 2.235 & 1.927 & 1.449 & 0.606 & 0.695 \\
\hline C. D. $(P=0.05)$ & 6.421 & 4.665 & 4.022 & 2.754 & 1.265 & 1.450 \\
\hline
\end{tabular}

In conclusion, integrated nutrient supply which involves the conjunctive use of fertilizers and organic sources assumes greater importancein achieving higher yield potential, through its effective vegetative growth and reproductive growth. Ultimately, higher grain yield, straw yield, biological yield with harvest index lead to promising approach with regard to agriculture aspects. In farmer's affordable point of view, starting from examining inherent soil health quality up to fetching maximum production, productivity and profitability with higher economic returns in fulfilling needs of hungry farmers.

\section{Acknowledgement}

I am grateful for ever-inspiring guidance, constant encouragement, keen interest and scholarly comments and constructive suggestions throughout the course of my studies and investigation, from, head of the department and staff, department of soil science and agricultural chemistry, Sam Higginbottom university of agriculture, 
technology and sciences, Prayagraj, Uttar Pradesh.

\section{References}

Ali, K., Arif, M., Shah, S., Hussain, Z., Ali, A., Munir, S. and Sher, H. 2015. Effect of organic and inorganic nutrients sources on phenology and growth of wheat. Pakistan Journal of Botany. 47(6): 2215-2222.

Amanullah, J. and Noor, M. 2014. Wheat response to farm yard manure and nitrogen fertilization under moisture stress conditions. Journal of Plant Nutrition. 34:732-742.

Bashan, Y. and De-Bashan, L. E. 2005. Plant growth-promoting. Encyclopedia of soils in the environment. 1:103-15.

Borse, D. K., Usadadia, V. P. and Thorave, D. S. 2019. Nutrient management in wheat (Triticum aestivum L.) under partially reclaimed coastal salt affected soil of South Gujarat. Int.J.Curr.Microbiol. App.Sci. 8(5): 1590-1599.

Brar, B. S., Singh, J., Singh, G. and Kaur, G. 2015. Effect of long-term application of inorganic and organic fertilizers on soil organic carbon and physical properties in maize-wheat rotation. Agronomy. 5:220238.

Chopra, R., Sharma, M., Sharma, S. K., Nepalia, V., Jain, H. K. and Singh, A. 2016. Effect of integrated nutrient management on growth and yield of wheat (Triticum aestivum L.) in Haplustepts. International Journal of Science and Nature. 7(3): 622628.

Ghanshyam, Kumar, R. and Jat, R. K. 2010. Productivity and soil fertility as effected by organic manures and inorganic fertilizers in green gram (Vigna radiate)-wheat (Triticum aestivum) system. Indian Journal of Agronomy. 55(1): 16-21.

Gomez, K. A. and Gomez, A. A. 1984. Statistical Procedures for Agricultural Research. An International Rice Research Institute Book. A Wiley Inter science, John Wiley and Sons Inc., New York, USA.

Goswami, 2007. Response of wheatto nitrogen and zinc application. Ann Agric Res New
Series. 28 (1): 90-91.

Grain and Feed Annual, 2019. The report contains assessments of commodity and trade issues made by USDA staff and not necessarily statements of official U.S. government policy. Grain and Feed Annual.1-42.

Jat, M. K., Purohit, H. S., Singh, B., Garhwal, R. S. and Choudhary, M. 2013. Effect of integrated nutrient management on yield and nutrient uptake in sorghum (Sorghum bicolor). Indian Journal of Agronomy. 58 (4): 543-547.

Jat, L. K., Singh, S.K., Latare, A. M., Singh, R. S. and Patel, C. B. 2013. Effect of dates of sowing and fertilizer on growth and yield of wheat (Triticum aestivum L.) in an Inceptisol of Varanasi. Indian Journal of Agronomy. 58(4): 611-614.

Kandil, A. A., El-Hindi, M. H., Badawi, M. A., ElMorarsy, S. A. and Kalboush, F. A. H. M. 2011. Response of wheat to rates of nitrogen, biofertilizers and land leveling. Crop and Environment. 2(1): 46-51.

Kaushik, M. K., Bishnoi, N. R. and Sumeriya, H. K. 2012. Productivity and economics of wheat as influenced by inorganic and organic sources of nutrients. Annals of Plant and Soil Research.14(1): 61-64.

Kumar, D., Purakayastha, T. J. and Shivay, Y. S. 2015.Long-term effect of organic manures and bio fertilizers on physical and chemical properties of soil and productivity of ricewheat system. International Journal of Bioresource and Stress Management. 6(2):176181.

Lehoczky, E., Kismanyoky, A., Lencse, T. and Nemeth, T.2012. Effect of different fertilization methods and nitrogen doses on the weediness of winter wheat. Communications in Soil Science and Plant Analysis. 43(1-2):341-345.

Meena, R., and Meena, R. S. 2013. Effect of INM on yield, nutrient content and soil fertility status after harvest the wheat (Triticum aestivum L.) crop. Environment and Ecology. 31(2B): 967-970.

Noreen, F. and Noreen, S. 2014. Effect of different fertilizers on yield of wheat International Journal of Science and Research. 3(11).

Pandey, Madhulika and Singh, T. 2015. Effect of 
intercropping systems and different levels of nutrients on dry matter accumulation and physiological growth parameters of bed planted wheat. Indian Journal of Science and Technology. 8(11): 54-230.

Patel, H. K., Sadhu, A. C., Lakum, Y. C. and Suthar, J. V. 2014.Response of integrated nutrient management on wheat (Triticum aestivum L.) and its residual effect on succeeding crop. Int.J. Agric.Sc \& Vet.Med. 2(4).

Rehman, S., Khalil, S. K., Muhammad, F., Rehman, A., Khan, A. Z., Amanullah, Saljoki, R. A., Zubair, M. and Khalil, I. H. 2010. Phenology, leaf area and grain yield of rainfed wheat influenced by organic and inorganic fertilizer. Pak.J.Bot. 42 (5):36713685.

Sharma, R. 2009. Effect of long term integrated nutrient management system on soil and crop productivity in rice-wheat crop sequence. Thesis submitted to CSK Himachal Pradesh Krishi Vishwavidyalaya, Palampur (HP) in partial fulfillment of the requirements for the degree of Ph.D. (Agronomy).

Singh, N. K., Chaudhary, F. K. and Patel, D. B. 2013. Effectiveness of Azotobacter bioinoculant for wheat grown under dryland condition, Journal of Environmental Biology. 34:927-932.

Singh, H., Singh, M. and Singh, N. 2016. Integration of organic and chemical fertilizers as affected by growth and yield of wheat (Triticum aestivum). Indian Journal of Ecology.43 (1): 80-83.

Singh, O., Kumar, S. and Awanish, 2012. Productivity and profitability of rice as influence by high fertility levels and their residual effect on wheat. Ind. J. Agron. 57(2): 143-147.

Singh, R. V. and Kumar, R. 2010. Effect of organic and inorganic fertilizers on growth yield and quality and nutrients uptake of wheat under late sown condition. Progressive Agriculture. 10(2):341-344.

Soleimanzadeh, H., and Gooshchi, F. 2013. Effects of Azotobacter and nitrogen chemical fertilizer on yield and yield components of wheat (Triticum aestivum L.). World Applied Sciences Journal. 21(8):1176-1180.

Verma, V. K., Singh, V., Choudhary, S., Tripathi, A. K. and Srivastava, A. K. 2015.Effect of organic manures and microbial inoculants superimposed over inorganic fertilizers on production and profitability of wheat (Triticum aestivum). Current Advances in Agricultural Sciences. 7(2): 129-132.

Yadav, D. S., Kumar, V. and Yadav, V. 2009. Effect of organic farming on productivity, soil health and economics of rice (Oryza sativa)-wheat (Triticum aestivum) system. Indian Journal of Agronomy.54(3): 267271.

Zahoor, 2014. Influence of integrated use of chemical and organic fertilizers on yield and yield components of wheat. Intl J Agri Crop Sci. 7(1):21-25.

\section{How to cite this article:}

Ramanandan, L. G., Narendra Swaroop, Arun Alferd David and Tarence Thomas. 2020. Influence of Integrated Nutrients on Growth and Yield Attributes of Wheat (Triticum aestivum L.) Crop [Cv.PBW-343] in Inseptisol. Int.J.Curr.Microbiol.App.Sci. 9(06): 2781-2794. doi: https://doi.org/10.20546/ijcmas.2020.906.337 